\title{
A comparison of thermogravimetric characteristics of fresh and used engine oils
}

\begin{abstract}
The requirements set for engine oils are nowadays very high, varied, often contradictory and significantly go beyond the classic functions of engine oils. Also for the testing of engine oils, many different and advanced research methods are currently used. This article describes tests of fresh and used oil from a diesel engine using thermogravimetric analysis. This method was also used to determine the soot content of the used oil. The tests showed that the thermograms of fresh and used oil are similar, however in the oil used in the diesel engine the soot content increases.
\end{abstract}

Key words: engine oil, thermogravimetric analysis, TGA, soot content

\section{Introduction}

The constant development of the construction of internal combustion engines is associated with an increase in their efficiency. Modern engines are therefore exposed to increasing thermal and mechanical loads. The proper and reliable operation of an internal combustion engine depends on many factors. The most important such factors include the use of engine oil with appropriate parameters and quality. Despite the increasing pressures and temperatures of combustion in modern engines, it is expected to reduce oil consumption and extended periods of its change. The requirements set for modern engine oils are therefore very high, varied, often contradictory and significantly go beyond the classic functions of oil, such as: reduction of friction, sealing, cooling, cleaning, corrosion protection, vibration damping.

For modern engine oils it is also expected [6]:

- low toxicity of oil combustion products,

- small changes in viscosity as a function of temperature,

- simultaneously low viscosity and volatility,

- low temperature fluidity,

- keeping the engine elements clean,

- resistance to sludge and sediment formation,

- no impact on the engine seals,

- no impact on exhaust gas aftertreatment.

The very wide and varied requirements imposed on engine oils are connected with the necessity of using various methods of testing. This article describes tests of fresh and used engine oils using thermogravimetric analysis. This method was also used to determine the soot content of the used oil.

\section{Soot in engine oil}

The mechanism of soot formation in the internal combustion engines has not been fully understood. The author of this article discusses the current views on the creation of soot in diesel engines in his work [5]. There is no doubt that the process of creating soot in the engine is very short and complex. The fuel particles generally contain from 12 to 22 carbon atoms and approximately twice as many hydrogen atoms. Within a few milliseconds, soot particles containing thousands of carbon atoms and about ten times less hydrogen atoms are produced. A more detailed analysis of this process indicates that it takes place in several stages. Pyrolytic reactions lead to the breakdown of fuel particles and the formation of soot precursors, which participate in the nucleation process of the first visible particles (nuclei) with a diameter below $3 \mathrm{~nm}$. Next, the process of growth occurs, connected with the attachment of carbon atoms and the removal of hydrogen atoms. As a result, spherules with a diameter of $20-50 \mathrm{~nm}$ are formed. At the same time, growth and agglomeration of spherules occurs, which leads to formation of particle aggregations. Another of the processes, i.e. oxidation, gives the opposite effects to the above-mentioned ones, namely removing soot at each of its development phases: precursors, nuclei, spherules and agglomerates.

The smallest possible to be observed under the electron microscope soot particles have a diameter of about $1.5 \mathrm{~nm}$ (molecular weight about $1600 \mathrm{amu}$ ). The reference [2] presents the opinion that the first distinguishable soot particles that pass from the gas phase and the molecular system have masses of the order of 650-700 amu (e.g. $\mathrm{C}_{54} \mathrm{H}_{30}$ ). According to these assumptions, soot nuclei are about $1 \mathrm{~nm}$ in diameter.

The soot nuclei formed begin to grow. The increase in the surface of the particles leads to the formation of spherules, which are the primary element (monomer) of the subsequently formed carbon agglomerates. This process is also responsible for the spherulite layered microstructure. Distant regions have an ordered crystallite structure, while the central region created by the nucleation process is amorphous (it also contains more hydrogen).

The growth process does not only apply to individual particles, but also runs in parallel with their agglomeration. Deposition of successive carbon layers on the surface of the agglomerates causes the individual spherules to merge together and become more and more difficult to distinguish within the framework of the structure. Agglomeration of particles is a mainly physical process, the number of particles decreases, and their total mass remains unchanged. The rate of agglomeration depends to a large extent on the number and size of the particles. Polydisperse particles agglomerate faster than monodisperse particles. Young particles are easier to combine with a more sticky surface.

Most of the soot produced in the combustion chamber of the engine escapes with the exhaust, but some of it passes through the piston rings and then mixes with the engine oil. The presence of soot in oil causes a number of adverse phenomena. It deteriorates, for example, the dispersing 
properties of the oil. High level of soot content in oil leads to a higher lubricant viscosity impeding oil flow and to carbon deposition in the piston ring. It will also affect antiwear lubricant additives resulting in increased engine wear and premature engine failures.

The tests described by Mruk [7] showed a significant negative effect of soot in engine oil on the tribological properties of this lubricant. For two different types of friction nodes: with a concentrated point contact of four balls and with a spread contact for the matching pair roller-block, it was found that in comparison to lubrication with neat oil, the increase of frictional forces and wear of elements increases with increasing soot in oil. This increase is already very clear for the soot content of $5 \%$.

\section{Test apparatus and procedures}

The studies described in the paper include determination of thermogravimetric characteristics of fresh and used engine oil of the same type. The test oil was $5 \mathrm{~W}-30$, API SN/CF, ACEA C3 class oil (Table 1). The sample of used oil came from a passenger car with a six-cylinder turbocharged common rail diesel engine with a capacity of 3.0 $\mathrm{dm}^{3}$. The oil was used during the mileage of the car of $16000 \mathrm{~km}$.

Table 1. Typical characteristics of the tested fresh engine oil [3]

\begin{tabular}{|l|c|c|c|}
\hline Name & Method & Units & Value \\
\hline Density @ $15^{\circ} \mathrm{C}$ & ASTM D4052 & $\mathrm{g} / \mathrm{ml}$ & 0.8524 \\
\hline Kinematic viscosity @ $100^{\circ} \mathrm{C}$ & ASTM D445 & $\mathrm{mm}^{2} / \mathrm{s}$ & 12.1 \\
\hline Viscosity, CCS $-30^{\circ} \mathrm{C}(5 \mathrm{~W})$ & ASTM D5293 & $\mathrm{mPa} \mathrm{s}$ & 5750 \\
\hline Kinematic viscosity @ $40^{\circ} \mathrm{C}$ & ASTM D445 & $\mathrm{mm}^{2} / \mathrm{s}$ & 70 \\
\hline Viscosity index & ASTM D2270 & - & 173 \\
\hline Pour point & ASTM D97 & ${ }^{\circ} \mathrm{C}$ & -42 \\
\hline Flash point, PMCC & ASTM D93 & ${ }^{\circ} \mathrm{C}$ & 204 \\
\hline Ash, sulphated & ASTM D874 & $\%(\mathrm{~m} / \mathrm{m})$ & 0.8 \\
\hline
\end{tabular}

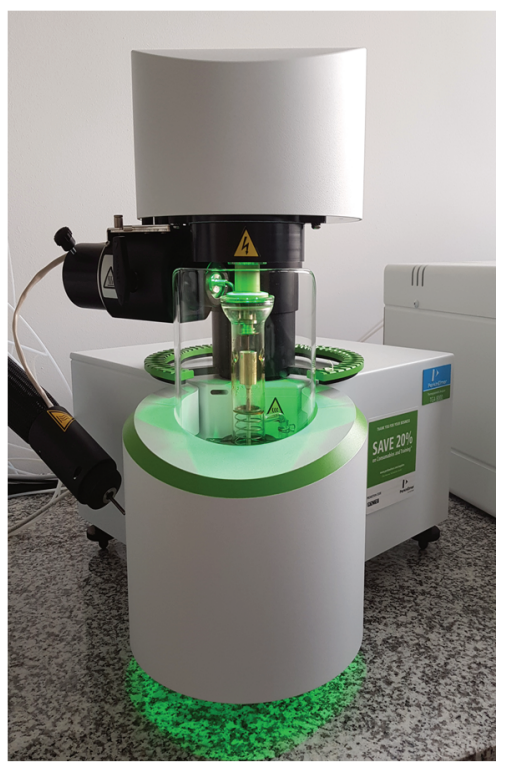

Fig. 1. PerkinElmer thermogravimetric analyzer TGA 8000
Thermogravimetric characteristics of oils were determined using a PerkinElmer thermogravimetric analyzer TGA 8000. Thermogravimetric analyzer (abbreviation: TGA) measures the change in mass of the sample as it is heated, cooled, or held at a constant temperature in a controlled atmosphere. Table 2 shows the characteristics of TGA 8000 and Figure 1 shows the picture of TGA 8000.

Table 2. Specifications of TGA 8000 thermogravimetric analyzer used in the research [4]

\begin{tabular}{|c|c|c|}
\hline Design & & $\begin{array}{l}\text { A vertical design with a high sensi- } \\
\text { tivity balance and quick response } \\
\text { furnace. The balance is located above } \\
\text { the furnace and is thermally isolated } \\
\text { from it. A precision hang-down wire } \\
\text { is suspended from the balance down } \\
\text { into the furnace. At the end of the } \\
\text { hang-down wire is the sample pan. } \\
\text { The sample pan's position is repro- } \\
\text { ducible. }\end{array}$ \\
\hline \multirow{4}{*}{ Balance } & Sensitivity & $0.1 \mu \mathrm{g}$ \\
\hline & Capacity & $1300 \mathrm{mg}$ \\
\hline & Accuracy & better than $0.02 \%$ \\
\hline & Precision & $0.01 \%$ \\
\hline \multirow{4}{*}{ Temperature } & Furnace & $\begin{array}{l}\text { Low mass }(<10 \mathrm{~g}) \text {; Platinum heating } \\
\text { element with ceramic protective } \\
\text { coating; resistant to inert and oxida- } \\
\text { tive gas over the full temperature } \\
\text { range. }\end{array}$ \\
\hline & Range & $-20^{\circ} \mathrm{C}$ to $1200^{\circ} \mathrm{C}$ \\
\hline & Scan rates & $0.1^{\circ} \mathrm{C} / \mathrm{min}$ to $500^{\circ} \mathrm{C} / \mathrm{min}$ \\
\hline & Precision & $\pm 1^{\circ} \mathrm{C}$ \\
\hline \multirow{2}{*}{ Cooling } & Method & Forced air cooled with an external fan \\
\hline & Cycle time & $1100^{\circ} \mathrm{C}$ to $50^{\circ} \mathrm{C}<13 \mathrm{~min}$ \\
\hline Sample Pans & & Platinum or ceramic $(60 \mu \mathrm{L})$ \\
\hline \multirow{4}{*}{ Atmosphere } & $\begin{array}{l}\text { Sample } \\
\text { environment }\end{array}$ & $\begin{array}{l}\text { Static or dynamic, including nitrogen, } \\
\text { argon, helium, carbon dioxide, air, } \\
\text { oxygen, or other inert or reactive } \\
\text { gases. Analyses done at normal or } \\
\text { reduced pressures. }\end{array}$ \\
\hline & $\begin{array}{l}\text { Gas } \\
\text { control }\end{array}$ & $\begin{array}{l}\text { Balance purge (Mass-flow con- } \\
\text { trolled); Sample purge (switch be- } \\
\text { tween } 2 \text { gases; Mass-flow controlled); } \\
\text { Reactive purge. }\end{array}$ \\
\hline & $\begin{array}{l}\text { Gas } \\
\text { mixing }\end{array}$ & Up to 3 gases \\
\hline & Vacuum & $10^{-5}$ Torr \\
\hline Autosampler & & 48-position \\
\hline
\end{tabular}

Thermogravimetric characteristics of the tested oils were determined according to the temperature program based on the temperature program described in the ASTM D5967 standard. ASTM D5967 is a test method which covers engine test procedures for evaluating diesel engine performance characteristics including viscosity and soot concentrations. Annex A4 is a recommendation on how to measure soot in engine oils. Details of the thermogravimetric analyzer working conditions during the tests are presented in Table 3. Pyris software version 13.3.1 was used to analyze the obtained results. 
Table 3. TGA experimental conditions

\begin{tabular}{|c|c|c|}
\hline $\begin{array}{l}\text { Instrument } \\
\text { conditions }\end{array}$ & $\begin{array}{l}\text { ASTM D5967 } \\
\text { Annex A4 [8] }\end{array}$ & $\begin{array}{l}\text { Conditions applied } \\
\text { in this work }\end{array}$ \\
\hline $\begin{array}{l}\text { Temperature } \\
\text { program }\end{array}$ & $\begin{array}{l}\text { 1. Hold for } 1 \mathrm{~min} \text { at } 50^{\circ} \mathrm{C} \\
\text { 2. Heat from } 50^{\circ} \mathrm{C} \text { to } \\
550^{\circ} \mathrm{C} \text { at } 100^{\circ} \mathrm{C} / \mathrm{min} \\
\text { 3. Hold for } 1 \mathrm{~min} \text { at } 550^{\circ} \mathrm{C} \\
\text { 4. Heat from } 550^{\circ} \mathrm{C} \text { to } \\
650^{\circ} \mathrm{C} \text { at } 100^{\circ} \mathrm{C} / \mathrm{min} \\
\text { 5. Heat from } 650^{\circ} \mathrm{C} \text { to } \\
750^{\circ} \mathrm{C} \text { at } 100^{\circ} \mathrm{C} / \mathrm{min} \\
\text { 6. Hold for } 5 \mathrm{~min} \text { at } 750^{\circ} \mathrm{C}\end{array}$ & $\begin{array}{l}\text { 1. Hold for } 4 \mathrm{~min} \text { at } \\
50^{\circ} \mathrm{C} \\
\text { 2. Heat from } 50^{\circ} \mathrm{C} \text { to } \\
550^{\circ} \mathrm{C} \text { at } 50^{\circ} \mathrm{C} / \mathrm{min} \\
\text { 3. Hold for } 2 \mathrm{~min} \text { at } \\
550^{\circ} \mathrm{C} \\
\text { 4. Heat from } 550^{\circ} \mathrm{C} \text { to } \\
650^{\circ} \mathrm{C} \text { at } 10^{\circ} \mathrm{C} / \mathrm{min} \\
\text { 5. Heat from } 650^{\circ} \mathrm{C} \text { to } \\
750^{\circ} \mathrm{C} \text { at } 10^{\circ} \mathrm{C} / \mathrm{min} \\
\text { 6. Hold for } 15 \mathrm{~min} \text { at } \\
750^{\circ} \mathrm{C}\end{array}$ \\
\hline Pan type & Platinum & Ceramic \\
\hline $\begin{array}{l}\text { Balance } \\
\text { purge }\end{array}$ & $40 \mathrm{ml} / \mathrm{min}$ & $60 \mathrm{ml} / \mathrm{min}$ \\
\hline $\begin{array}{l}\text { Sample } \\
\text { purge }\end{array}$ & $\begin{array}{l}\mathrm{N}_{2}, 30 \mathrm{ml} / \mathrm{min} \\
\text { for step } 1 \text { to } 4 \\
\mathrm{O}_{2}, 30 \mathrm{ml} / \mathrm{min} \\
\text { for step } 5 \text { and } 6\end{array}$ & $\begin{array}{l}\mathrm{N}_{2}, 40 \mathrm{ml} / \mathrm{min} \\
\text { for step } 1 \text { to } 4 \\
\text { Air, } 40 \mathrm{ml} / \mathrm{min} \\
\text { for step } 5 \text { and } 6\end{array}$ \\
\hline $\begin{array}{l}\text { Sample } \\
\text { quantity }\end{array}$ & Around $10 \mathrm{mg}$ & Around $20 \mathrm{mg}$ \\
\hline
\end{tabular}

\section{Test results and discussion}

The obtained thermograms for fresh and used oil are presented in Figures 2 and 3 respectively. In both cases the course of the curve is very similar. This allows us to believe that the used oil was of high quality - it was resistant to hard conditions prevailing in the engine and/or was used in not very unfavorable engine operation conditions. It was certainly favored by the large volume of oil in the engine (ca. $7 \mathrm{dm}^{3}$ ) and oil cooler, as well as good technical condition of the engine.

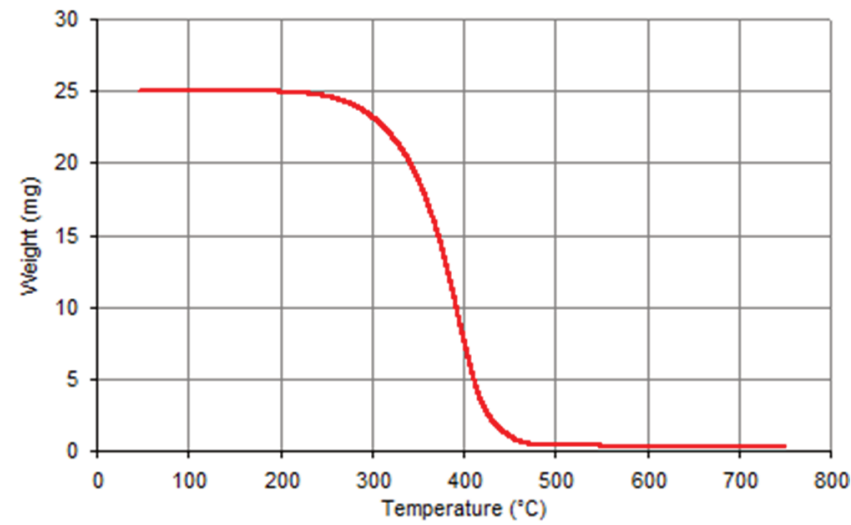

Fig. 2. Thermogram of fresh 5W-30 engine oil obtained during the temperature program presented in the Table 3

As it can be seen in Figure 4, 90\% of the mass of the samples of both oils distilled (under conditions of neutral atmosphere $-\mathrm{N}_{2}$ ) in the temperature range of: $290-440^{\circ} \mathrm{C}$. The characteristic distillation temperatures, i.e. T10, T50 and T90, were very similar for the samples of both oils (temperatures at which 10, 50 and $90 \%$ of the samples were evaporated respectively). Strictly speaking, they were by a few degrees Celsius higher for fresh oil, respectively: T10 by $5^{\circ} \mathrm{C}$, T50 by $8^{\circ} \mathrm{C}$ and $\mathrm{T} 90$ by $3^{\circ} \mathrm{C}$. It proves, among others about the fact that despite the high mileage of used engine oil (16 thousand $\mathrm{km}$ ), it was only slightly contaminated with fuel.

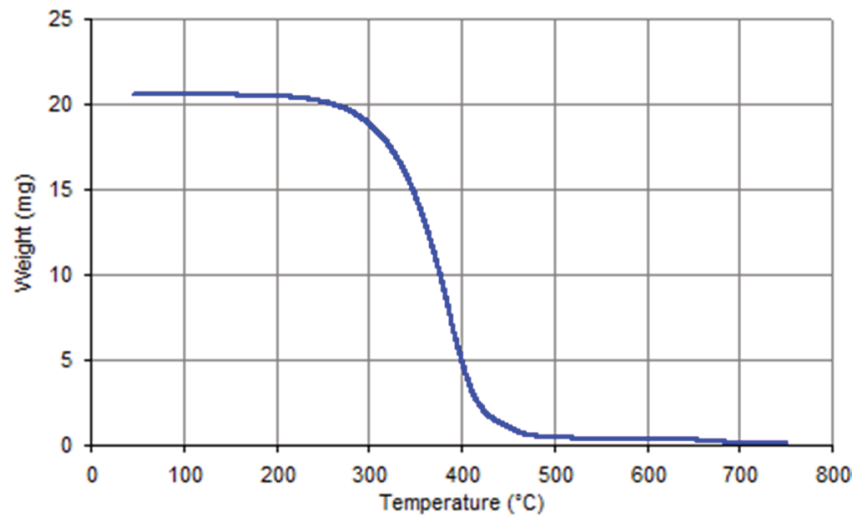

Fig. 3. Thermogram of used 5W-30 engine oil obtained during the temperature program presented in the Table 3

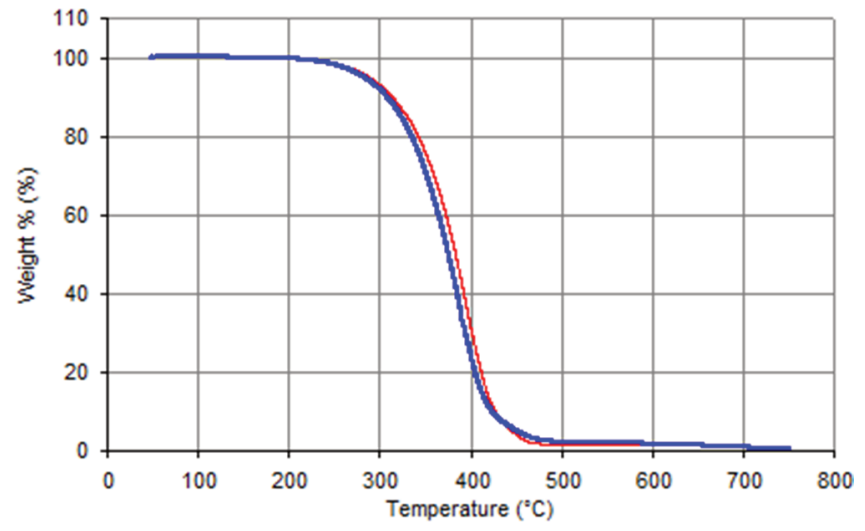

Fig. 4. Comparison of thermograms of fresh (red curve) and used (blue cirve) $5 \mathrm{~W}$-30 engine oil obtained during the temperature program presented in the Table 3

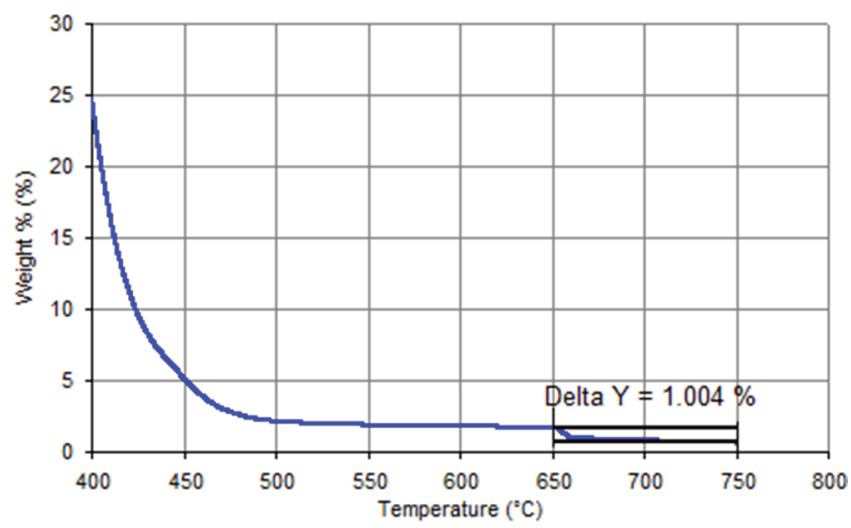

Fig. 5. Thermogram showing percentage soot content in used 5W-30 engine oil sample

The thermogravimetric analysis made also allows determination of the soot content in the engine oil. The first weight loss that occurs as the sample is heated is the evaporative loss of the lubricating oil and any other volatile materials present. All that remains will be soot and other solid residues present in the sample. Switching the purge gas from nitrogen to oxygen or air will remove any soot present in the sample. The calculation of soot content was performed for the weight loss that commences after switching 
over the purge gas from nitrogen to oxygen or air at $650^{\circ} \mathrm{C}$ up to the temperature where constant residue was obtained around $750^{\circ} \mathrm{C}[1]$.

Figure 5 shows the enlarged part of the thermogram of used oil and the loss of mass of the sample under the conditions of the oxidizing atmosphere. The loss corresponds to the content of soot in the used oil at the level of $1 \%(\mathrm{~m} / \mathrm{m})$. This is a low content considering the mileage of the oil and the fact of its use in the diesel engine.

\section{Summary}

Thermogravimetric analysis is a modern tool used, among others for testing engine oils, both fresh and used. The advantage of this analysis is the small sample mass necessary to perform the tests (just a few milligrams). In the case of engine oils, thermogravimetric analysis is mainly used to assess the content of soot in oil in accordance with ASTM D5967. High soot content in engine oil is unfavorable and can lead to damage or accelerated engine wear. The level of soot in oil is one of the criteria for considering motor oil to be used up. The analysis of the engine oil thermogram also brings a lot of other information, such as the level of oil contamination (e.g. by fuel) or changes in the oil fractional composition during operation. Volatiles formed from oil during its heating in a thermogravimetric analyzer can then be analyzed, which is a next potential source of important information. Such an analysis can be performed, among others by means of FTIR spectrometer and/or gas chromatograph with mass detector.

\section{Bibliography}

[1] DESHMUKH, P. Soot content determination of in-service lubricants of diesel engine as per ASTM D5967 Annex A4. Perkin Elmer application note - thermal analysis. https://www.perkinelmer.com/lab-solutions/resources/docs/ APP_Soot_Content_Determination_Diesel_Engine(012934 A_01).pdf

[2] GRIFFITHS, J.F., BARNARD, J.A. Flame and combustion. Blackie Academic and Professional. London, 1995.

[3] https://msdspds.castrol.com/bpglis/FusionPDS.nsf/Files/FD 182837C6D9427B802582D200644540/\$File/BPXE-B2WP FG.pdf

[4] https://sim-gmbh.de/images/PDF_Dokumente_neu/GCMS/ TGA_8000_Specification_Sheet_012248_01_SPC.pdf

[5] KOZAK, M. Study on the impact of diesel fuel oxygenated compounds on the exhaust emissions from diesel engines.

Polish. Publishing House of Poznan University of Technology. Poznan 2013.

[6] MERKISZ, J. Ecological problems of internal combustion engines. Polish. Publishing House of Poznan University of Technology. Poznan 1999.

[7] MRUK, A. Effects of soot contents in engine oil on its tribological characteristics. Technical Transactions - Mechanics. 2008, 7-M.

[8] SATPUTE, Y. Estimation of soot content in engine oil using Thermo Gravimetric Analysis (TGA) as per ASTM D5967 Method. Perkin Elmer application note - thermal petro. http://www.perkinelmer.com/CMSResources/Images/20130 104 6-Estimation $\% 20$ of $\% 20$ soot $\% 20$ content $\% 20$ in $\% 20$ eng ine $\% 20$ oil.pdf 